\title{
Prolang-tutkimus kartoitti työelämän kielitaitotarpeita
}

\author{
Kielitaidosta on yhä suurempi kysyntä. Kysymys \\ ei ole vain siitä, mitä vieraita kieliä tarvitaan, \\ vaan myös siitä, miten eri kieliä osataan. \\ Ovathan arkipäivän asioimiskieli, seurustelukieli, \\ neuvottelu- ja kongressikieli, kirjoituskieli tai \\ tulkkauskieli kaikki eri taitolajeja. Voisimmeko \\ kansainvälisessä kanssakäymisessä näyttää \\ suomalaista sisuamme heittäytymällä \\ rohkeammin seurustelutilanteisiin? Vielä kuulee \\ ulkomaalaisten moittivan suomalaisia siitä, että \\ vetäydymme seurustelutilanteissa kovin \\ liukkaasti puhumaan suomea omissa \\ porukoissamme.
}

Runsas vuosi sitten opetushallitus tutkitutti tilastokeskuksella suomalaisten vieraiden kielten osaamista. Tulokset perustuivat vastaajien omaan arvioon. Miltei miljoona suomalaista on äidinkielensä varassa. He ovat pääasiassa työläisiä, matalasti koulutettuja, maaseudulla asuvia ja jo ikääntyviä ihmisiä.

Nyt opetushallitus on kartoittanut yritysten henkilöstön käsitykset vieraiden kielten tarvitsemisesta työssä. Kolme neljästä katsoo tarvitsevansa työssään kahta tai useampaa vierasta kieltä. 12 prosenttia tarvitsee jopa neljää tai useampaa kieltä. Joka viides kertoo tulevansa toimeen yhdellä vieraalla kielellä. Kokonaan ilman vieraiden kielten taitoa selviää mielestään vain neljä prosenttia yritysten henkilöstöön kuuluvista.

\section{Suullinen kielitaito korostuu työtilanteissa}

Teknisissä ja kaupallisissa tehtävissä kielenkäyttötilanteita ovat rutiinipuhelut ja asiakaskontaktit, kuten messut, asiakaspalvelu ja sosiaaliset tilanteet. Tärkeitä ovat myös sähköpostien, faksien ja lyhyiden viestien kirjoittaminen sekä käsikirjojen, ohjeiden ja tuotekuvausten lukeminen.

Kaikki teollisuuden henkilöstöryhmät sanovat tarvitsevansa vieraita kieliä keskimäärin enemmän suulliseen kanssakäymiseen kuin lukemiseen tai kirjoittamiseen. Eniten suullista viestintää tarvitaan kaupallisissa, teknisissä ja sihteerintehtävissä; eniten kirjallista viestintää kaupallisissa ja johtotehtävissä. Tekninen henkilöstö tarvitsee 
eniten vieraita kieliä lukemiseen.

Kielenkäyttötilanteista vaikeimmiksi koetaan kokoukset ja neuvottelut, asiakaskontaktit ja esitysten pitäminen. Muita vaativia tilanteita ovat keskustelut toimituksista, asennuksista ja kunnossapidosta, vierailut sekä haastattelu- ja tulkintatilanteet. Kielenkäyttötilanteessa kielitaidon puutteet ovat vain osa ongelmaa. Muut syyt liittyvät kokonaisviestinnän onnistumiseen. Tilanne saattaa olla kaiken kaikkiaan mutkikas. Vastapuolen puheen korostus ja toimintatapa voi olla outo. Kulttuuritausta vaikeuttaa ymmärtämistä. Puhujan oma tietämys ei välttämättä riitä. Vastapuoli ei ymmärrä puhujan ongelmaa tai esittämiä syitä. Kun tavalliset kielenkäyttötilanteet ovat useimmiten kahden henkilön välisiä, vaativissa tilanteissa henkilöitä on mukana useampia. Niissä ryhmä neuvottelee ryhmän kanssa tai yksilö neuvottelee ryhmän kanssa.

\section{Mikä saa viestinnän on $n$ is t u m a a n}

Tutkimukseen haastateltujen toimihenkilöiden mukaan tärkeintä on, että osapuolet ymmärtävät toisiaan huolimatta korostuksesta, kielestä tai kulttuuritaustasta. On tärkeää osata herättää kiinnostusta asiakkaassa. On osattava asettaa sanansa vastapuolen tasolle niin, että asiakas ymmärtää. On tärkeää sopia, mitä termit tarkoittavat.

Muut onnistumistekijät liittyvät kokonaisviestintään. Puhekumppaneiden on osattava luoda hyvä ilmapiiri ja osoittaa kohteliaisuutta kumppanin hyväksymällä tavalla. Puhujan on hallittava asiasisältö läpikotaisin ja erotettava oleelliset asiat epäoleellisista. On kyettävä keskittymään ja osattava olla hyvä kuuntelija.

Tilanteet eivät jakaannu kuullun ymmärtämiseen, puhumiseen, lukemiseen ja kirjoittamiseen. Erilaiset osataidot ovat läsnä samassa tilanteessa sisäkkäin ja vuorotellen. Kokonaisuus on mutkikkaampi kuin osien summa. Siksi on tärkeää, että kieltenopetus jäljittelee niitä monitahoisia tilanteita, joita työelämässä tarvitaan.

\section{Vieraan kielen taidon vahvuudet ja heikkoudet}

Työntekijät pitävät vahvimpina puolinaan lukemista, kuullun ymmärtämistä sekä ammattisanaston hallintaa. He kokevat kuitenkin osaavansa liian harvoja kieliä. Suullinen taito ei myöskään riitä. On kuitenkin merkittävää, että viidennes vastaajista pitää myös suullista taitoa vahvuutenaan. Vieraiden kulttuurien tuntemus koetaan riittämättömäksi.

Henkilöstöpäälliköt näkevät työntekijöiden kielitaidon vahvuudet ja puutteet paljolti samoin kuin työntekijät. Tosin he arvioivat henkilöstön vahvuudeksi kirjoittamistaidon, mitä työntekijät pitävät yhtä usein heikkoutenaan. Henkilöstöpäälliköt epäilevät, että henkilöstön ammattikielen taidossa on puutteita; työntekijät sen sijaan arvelevat olevansa vahvoja ammattikielen taidossa.

\section{Uusien kielten tarve lis ä ä n ty mäs s ä}

Kansainvälistyminen näkyy kaikkien kielten tarpeen lisääntymisenä teollisuudessa. Eniten kasvaa englannin, sitten saksan, venäjän ja ranskan tarve. Ruotsin tarpeen arvellaan useimmissa yrityksissä pysyvän samana tai laskevan. Nousua ruotsin kielen tarpeelle povaa vain joka kolmas yritys, kun englannin tarpeen nousua ennustaa lähes 80 prosenttia yrityksistä.

Työntekijät näkevät kielten tarpeen tulevaisuudessa eri tavalla kuin henkilöstöpäälliköt. Englannista ollaan samaa mieltä, mutta saksan, venäjän ja ranskan tarpeen lisääntymiseen työntekijät uskovat harvemmin kuin työnantajan edustajat. Sen sijaan työntekijät uskovat ruotsin tarpeen lisääntyvän enemmän kuin työnantajat. Tulosten valossa näyttää siltä, että työntekijät haluavat nähdä niiden kielten tarpeitten lisääntyvän tulevaisuudessa, joita he jo osaavat, eikä kielten, joita he eivät osaa.

Yrityshenkilöstön tutkimuksessa esittämät kiel- 
tenopiskelutavoitteet seuraavalle viidelle vuodelle tuovat suuret markkinat kielikoulutusyrittäjille. Henkilöstö aikoo korottaa kielitaitoaan keskimäärin 2.1 tasoa $0-5$ asteikolla. Tämä tarkoittaa noin miljoonan markan investointia sataa toimihenkilöä kohti.

Esimerkiksi englantia ja saksaa hyvin tai erinomaisesti osaavien määrän on yli kaksinkertaistuttava. Opetushallituksen raportin mukaan on luotava uusi, ranskaa ja venäjää hyvin ja erinomaisesti osaavien ryhmä, kun näitä kieliä osataan nyt vain alkeis- ja keskitasolla. Ruotsissakin 18 prosenttia henkilöstöstä aikoo hankkia hyvän tai erinomaisen taidon viiden vuoden kuluessa.

\section{Kieltenopet ukselle palautetta työelämästä}

Tutkimuksessa pyydettiin sekä henkilöstöpäälliköiltä että henkilöstöltä palautetta erikseen ammatilliselle ja yleissivistävälle kieltenopetukselle.

Ammatillisen kieltenopetuksen vahvuuksia on työntekijöiden mukaan ammattiterminologian opettaminen. Ammatillinen kieltenopetus valmentaa opiskelijoita kohtalaisen hyvin työelämään. Heikkouksista ollaan samaa mieltä: suullista taitoa ei opeteta riittävästi, ja kielten osuus koulutuksesta on liian vähäinen.

Yleissivistävän kieltenopetuksen palaute on erilainen. Vahvuuksina sekä henkilöstöpäälliköt että henkilöstö näkevät, että peruskoulu ja lukio antavat hyvän peruskielitaidon ja keskittyvät kielioppiin. Mutta 58 prosenttia henkilöstöstä ja 41 prosenttia henkilöstöpäälliköistä on sitä mieltä, että suullista kielitaitoa ei kartuteta riittävästi.

Opetushallituksen Prolang-tutkimuksen (Marjatta Huhta. Language/Communication Skills in Industry and Business. - Report for Prolang/Finland. Opetushallitus 1999) keskeinen tulos on, että ammatillista kieltenopetusta voidaan kehittää palvelemman paremmin työelämää. Tämä voi tapahtua mm.

1 lisäämällä yhteyksiä oppilaitosten ja työelä- män välillä

1 kehittämällä kieltenopetuksen sisältöjä ja menetelmiä vastaamaan työelämän kysyntää

1 lisäämällä suullisen kielitaidon opetusta

1 opettamalla työelämän viestintää kokonaisvaltaisesti, yhteydessä muihin työelämän kannalta oleellisiin aiheisiin ja työtaitoihin

1 kehittämällä kielenopetusohjelmia niin, että opiskelijat tekevät erilaisia valintoja ja kielitaidon osaamispohja monipuolistuu

1 parantamalla kieltenopettajien koulutusta niin, että se antaa laaja-alaisempia valmiuksia kulttuurienvälisen viestinnän ja työelämän vientintätaitojen opetukseen

1 kehittämällä erityisesti miehille paremmin soveltuvaa kieltenopetusta, koska heidän kielivalintansa ovat suppeita ja työn kielivaatimukset laajoja ja vaativia sekä

1 lähettämällä opiskelijoita ulkomaille harjoitteluun ja työhön, koska työnantaja pitää näitä parhaimpina mittareina vieraiden kielten taidosta.

\section{Lisätietoja}

Tutkija Marjatta Huhta

Helsingin ammattikorkeakoulu

marjatta.huhta@hit.fi.

Marjatta Huhta (1999) Language/Communication Skills in Industry and Business. - Report for Prolang/ Finland. Helsinki: Opetushallitus.

Pikko Sartoneva (toim.) Vieraiden kielten osaaminen Suomessa - aikuisten kielitaidon arviointi. Opetushallitus $6 / 98$. 